\title{
К вопросу о полногеномном секвенировании иммунного к грибным заболеваниям вида Vitis Rotundifolia Michaux
}

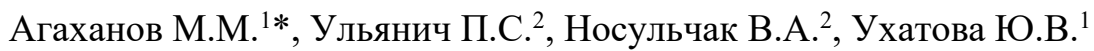 \\ ${ }^{1}$ Федеральный исследовательский иентр Всероссийский институт генетических ресурсов растений им. Н.И. Вавилова \\ (ВИР), Санкт-Петербург, Россия \\ ${ }^{2}$ Санкт-Петербургский государственный лесотехнический университет им. С.М. Кирова (СПбГЛТУ), \\ Санкт-Петербург, Россия \\ *e-mail: g.agakhanov@gmail.com
}

Ключевые слова: виноград, мускадиния, полногеномная сборка, донор устойчивости, полногеномное секвенирование, геномная сборка

Одним из уникальных источников генов устойчивости к оидиум и милдью для селекции винограда является североамериканский вид Vitis rotundifolia Michaux, относящийся к подроду Muscadinia. Этот вид можно считать практически иммунным к возбудителям оидиум и милдью, однако использовать этот ценный источник генов устойчивости для селекции европейских сортов винограда затруднительно.

Если виды подрода Euvitis легко скрещиваются между собой, то получить гибриды между V. vinifera (подрод Euvitis, 38 хромосом) и V. rotundifolia (подрод Muscadinia, 40 хромосом) ранее удавалось с большим трудом, при этом гибридные сеянцы становились фертильными только после их полиплоидизации. Очевидно, что ни созданный ранее селекционный гибридный материал с участием $V$. rotundifolia, ни материал, полученный вновь с целью поиска генов устойчивости к оидиуму, милдью и филлоксере, не удастся использовать целенаправленно без информации о геноме донора генов устойчивости - иммунного вида V. rotundifolia.

Нами было произведено два запуска на секвенаторе MinION (Oxford Nanopore Technologies) c использованием двух проточных ячеек типа R9.4.1. Перед запуском проводили диагностику ячеек с целью контроля их качества. По результатам диагностики на момент запуска на первой проточной ячейки FLO-MIN106D оказалось 1113 работоспособных белковых пор, - на второй - 1147.

Для ячейки № 2 ожидаемая длина фрагментов ДНК при приготовлении библиотеки составляла 20000 п.н. По результатам запуска, наибольшее число прочтений имело длину порядка 10000 п.н. В результате запуска двух проточных ячеек было прочитано 11 Гб (млрд пар оснований ДНК). Приблизительный размер генома Vitis vinifera L. $(2 n=38)$ составляет 435 Мб (млн оснований ДНК). Таким образом, возможное покрытие генома исследуемого вида V. rotundifolia, полученное в результате проведенного секвенирования, является приблизительно приблизительно двадцатикратным. Полученные данные позволяют перейти к следующему этапу исследований биоинформатическому анализу полученных данных секвенирования и полногеномной сборке.

Благодарности: Исследование выполнено при финансовой поддержке РФФИ в рамках научного проекта № 19-316-90007. 